NATAŠA Ž. ŠEKULJICA ${ }^{1}$, NEVENA Ž. PRLAINOVIĆ', NEVENA M. LUKIĆ ${ }^{2}$, ALEKSANDRA M. JAKOVLJEVIĆ SANJA Ž. GRBAVČIĆ ${ }^{1}$, DUŠAN Ž. MIJIN",,, ZORICA D. KNEŽEVIĆ-JUGOVIĆ2

${ }^{1}$ Innovation Center of Faculty of Technology and Metallurgy, University of Belgrade, Belgrade, Serbia, ${ }^{2}$ Faculty of Technology and Metallurgy, University of Belgrade, Belgrade, Serbia
Scientific paper

UDC:635.11:664.039

doi:10.5937/ZasMat1503335S

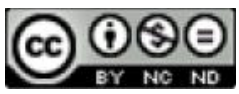

Zastita Materijala 56 (3)

$335-339$ (2015)

\title{
Immobilization of peroxidase from fresh horseradish extract for anthraquinone dye decolorization
}

\begin{abstract}
Synthetic dyes are used in all sectors of industry and represent a serious ecological problem. By the presence, anthraquinone dyes are right after the azo dyes. Unlike azo, anthraquinone dyes are considerably harder to degrade due to the presence of coupled aromatic rings in their structure. Horseradish peroxidase (HRP) proved to be an efficient and ecologically acceptable solution for synthetic dyes decolorization. For that reason, feasibility of peroxidase from fresh horseradish extract application in anthraquinone dye decolorization was the object of this research. Unpurified peroxidase $\left(1.5 \mathrm{mg} \mathrm{mL}^{-1}\right)$, was immobilized onto fumed silica by adsorption. In order to optimize the decolorization of anthraquinone dye Acid Violet 109 (AV 109) 0.1 IU of obtained immobilized HRP was applied in a batch reactor. Under the optimal conditions ( $\mathrm{pH}$ 4.0, dye concentration $30 \mathrm{mg} \mathrm{L}^{-1}$, hydrogen peroxide concentration $0.1 \mathrm{mM}$ ) $55.1 \%$ of initial dye concentration was decolorized, within $30 \mathrm{~min}$. In addition, compared to free enzyme, immobilized HRP showed higher resistance towards inhibitory influence of the dye and hydrogen peroxide.
\end{abstract}

Keywords: horseradish peroxidase, immobilization, dye, wastewater.

\section{INTRODUCTION}

The rapid development of industry sector leads to sharp increase in water consumption. The resulting wastewater is characterized with intense staining, high suspended solids, chemical (COD) and biochemical (BOD) oxygen demand [1]. Thus, proper treatment of these waters is necessary to protect humans and the environment. One of the biggest problems in wastewater streams are dyes because they are highly visible even in small amounts (1 ppm). Colored water, if discharged in to the natural recipient, has negative effects on living organisms. Besides, human health problems such as liver, brain, central nervous system damage can be caused by toxic waters. Among all synthetic dyes used in industry, azo and anthraquinone are the most frequently applied ones. The use of classic physical-chemical methods, with adsorption being most commonly used, could not resolve the problem of colored wastewaters.

${ }^{*}$ Corresponding author: Dušan Ž. Mijin email: kavur@tmf.bg.ac.rs

Paper received: 15.04.2015.

Paper accepted: 16.06.2015.

Paper is available on the website: www.idk.org.rs/casopis
The main drawback of this method is that anthraquinone dyes have high water solubility and they poorly adsorb, with lower rate and lesser extent of decolorization as compared to azo dyes. Besides, anthraquinone dyes are extremely resistant to degradation due to fused aromatic rings present in their structure [2,3]. The use of oxidoreductive enzymes (E.C. 1.11.1.X) gain researchers attention because of the mild reaction conditions, low energy consumption and harmless by-products [4, 5]. Use of horseradish peroxidase (E.C. 1.11.1.7) appeared to be very efficient as well as eco-friendly method for decolorization of wastewaters [4,6-8]. Disadvantages of free enzyme application such as: instability, denaturation, impossibility of recovery and purification, contamination or proteolysis can be overcome by using their immobilized counterparts $[9,10]$. However, decolorization of wastewaters on an industrial scale requires stable, efficient and economically justified biocatalysts. These requirements can be met if the decolorization reaction is followed by the use of immobilized peroxidase. Fumed silica seems to be very prospective support for the enzyme immobilization because of the high adsorption affinity towards organic molecules like proteins and polymers. For that reason it was chosen in this work as a support for the adsorption of HRP. This paper is 
focused on the development of immobilized biocatalyst for the decolorization of anthraquinone dye from wastewaters. For the immobilization, peroxidase from fresh extract of horseradish roots (Armoracia rusticana) without purification was used. As a method of immobilization, adsorption was selected. In order to find optimal conditions for the decolorization of AV 109 dye, the experiments were performed in a batch reactor. The optimal conditions: $\mathrm{pH}$,dye concentration and hydrogen peroxide concentration were evaluated. The obtained optimal parameters for decolorization with immobilized peroxidase were compared to the results obtained for the decolorization with free enzyme. Besides, operational stability of immobilized HRP was examined.

\section{EXPERIMENTAL}

\subsection{Materials}

Horseradish root was supplied from the local market. Pyrogaloll and fumed silica were supplied from Sigma-Aldrich (USA). Hydrogen peroxide was purchased from E. Merck (Darmstadt). Model dye used in this paper, C. I. Acid Violet 109, was obtained from Lanaset (Lanaset Violet B). All other chemicals used in this work were of analytical grade.

\subsection{Methods}

\section{Horseradish peroxidase extracts preparation}

Horseradish extract was prepared as follows: horseradish roots, after cleaning with water, were crushed in a grinder without addition of water. The resulting extract was stored at $4^{\circ} \mathrm{C}$ and used for the immobilization and dye decolorization studies.

\section{Protein content determination}

Immobilization efficiency was determined by measuring the amount of bound protein. The amount of bound protein was determined by subtracting the amount of protein in supernatant and filtrates from the offered protein mass, using modified method of Lowry [11].

\section{Activity assay of free and immobilized HRP}

Activity of free as well as immobilized HRP was determined using pyrogaloll as standard substrate. Shortly, the assay solution consist of: $1 \mathrm{~mL}$ of pyrogaloll $(0.013 \mathrm{M}), 10 \mathrm{~L}$ hydrogen peroxide (3\% $\mathrm{v} / \mathrm{v})$ and $10 \mathrm{~L}$ of enzyme solution; $3 \mathrm{~mL}$ of pyrogaloll $(0.013 \mathrm{M}), 30 \mathrm{~L}$ hydrogen peroxide $(3 \%$ $v / v)$ and predetermined mass of immobilized biocatalyst, for free and immobilized HRP respectively. The catalytic activity was monitored by following the change in apsorbance at $420 \mathrm{~nm}$.
One unit of the activity was defined as the amount of peroxidase that will form $1.0 \mathrm{mg}$ of purpurogallin from pyrogallol in $20 \mathrm{~s}$ at pH 7.0 and $20^{\circ} \mathrm{C}$ [12].

Immobilization of horseradish peroxidase

$100 \mathrm{mg}$ of fumed silica was suspended in 1.2 $\mathrm{mL}$ of enzyme solution ( $1.5 \mathrm{mg} \mathrm{mL}^{-1}$ ), prepared in the potassium phosphate buffer $0.1 \mathrm{M}, \mathrm{pH}$ 7.0. After $2 \mathrm{~h}$ shaking at room temperature immobilized HRP was removed from the supernatant and rinsed with immobilization buffer until no activity was detected in the filtrates. Immobilized HRP was stored at $4^{\circ} \mathrm{C}$ until use.

\section{Decolorization of anthraquinone dye AV 109}

Efficiency of obtained immobilized HRP was examined in the decolorization reaction of the selected anthraquinone dye, AV 109 often present in wastewater. In order to optimize the decolorization of AV 109 dye, using 0.1 IU of enzyme activity, $\mathrm{pH}$ (3.0, 4.0, 5.0, 7.0, 9.0), hydrogen peroxide (0.05$0.6 \mathrm{mM})$ and dye concentration (10-50 $\left.\mathrm{mg} \mathrm{L}^{-1}\right)$ were varied. The residual amount of dye was followed using UV-Vis spectrophotometer (UV Shimadzu 1700, Shimadzu Corporation, Kyoto, Japan) at maximum wavelength for tested dye $\left(\lambda_{\max } 590 \mathrm{~nm}\right.$ AV 109). Decolorization was calculated using following mathematical expression [6]:

$$
\text { Decolorization }(\%)=\left[\left(\frac{A_{0}-A_{t}}{A_{0}}\right)\right] \times 100
$$

where $A_{0}$ is the initial absorbance of untreated dye solutions (control) and $A_{t}$ is the absorbance of dye solutions after enzymatic treatment. Under the optimal conditions, immobilized HRP was subjected to reusability study in order to determine operational stability of obtained biocatalyst. Reuse of immobilized HRP was examined through consecutive cycles of AV 109 decolorization reaction. After first decolorization reaction, immobilized enzyme was separated from the reaction mixture, rinsed two times with immobilization buffer and applied in the next catalytic cycle.

\section{RESULTS AND DISSCUSION}

It was determined, after the immobilization, that $1 \mathrm{~g}$ of fumed silica adsorbe $3.4 \mathrm{mg}$ of protein and the obtained preparation showed the activity of $22.1 \mathrm{IU} \mathrm{g}^{-1}$. In order to make results comparable optimization experiments with free and immobilized HRP were done with the equal amount of the activity $(0.1 \mathrm{IU})$. In the first experimental set optimal $\mathrm{pH}$ and hydrogen peroxide concentration were evaluated. Results are presented in Fig. 1. 
a)

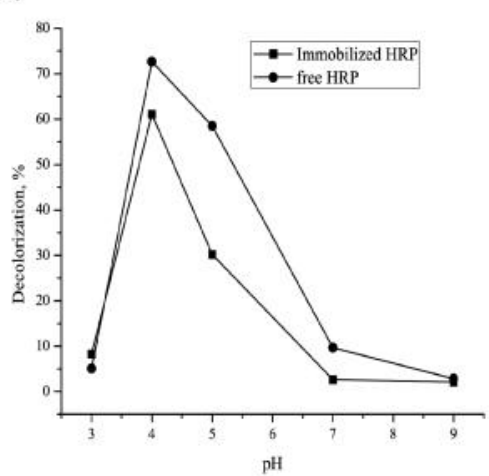

b)

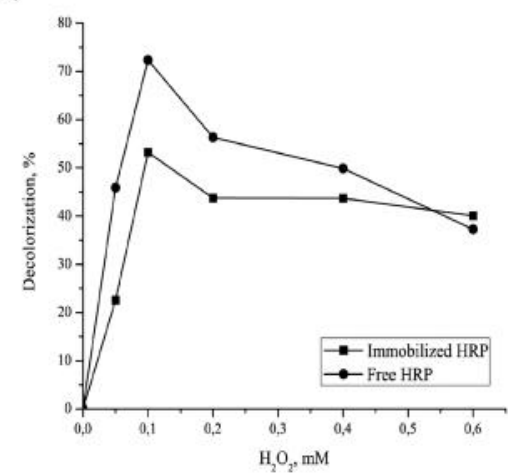

c)

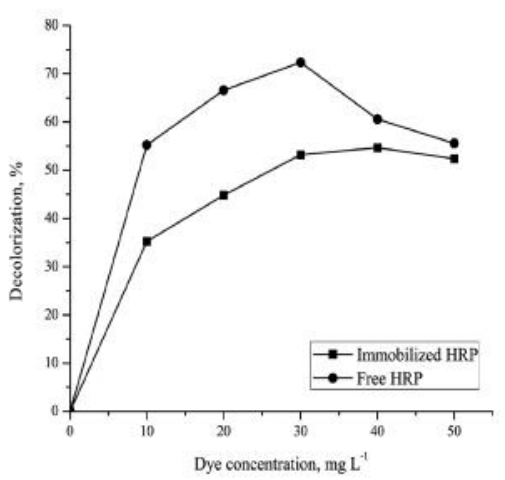

Figure 1 - Optimum a) pH (reaction volume $50 \mathrm{~mL}$, enzyme $0.1 \mathrm{IU}$, dye concentration $30 \mathrm{mg} \mathrm{L}^{-1}$, hydrogen peroxide concentration $0.1 \mathrm{mM}$ ); b) hydrogen peroxide concentration (reaction volume $50 \mathrm{~mL}$, enzyme

$0.1 \mathrm{IU}$, dye concentration $30 \mathrm{mg} \mathrm{L}^{-1}, \mathrm{pH} 4.0$ ); c) dye concentration (reaction volume $50 \mathrm{~mL}$, enzyme $0.1 \mathrm{IU}$, dye concentration $30 \mathrm{mg} \mathrm{L}^{-1}, \mathrm{pH} 4.0$, hydrogen peroxide concentration $0.1 \mathrm{mM}$, contact time $40 \mathrm{~min}$ )

Fig. 1a clearly indicates that both, free and immobilized HRP have optimum at $\mathrm{pH}$ 4.0. This can be explained by the fact that adsorption is immobilization technique with the mild conditions and that native conformation of the enzyme often does not change during the immobilization [13]. The similar orientation resulted in the similar affinity of the enzyme molecule towards substrate. $\mathrm{pH} 4.0$ seems to be the best, where $72.7 \%$ and $61.1 \%$ of AV 109 dye was decolorized using free and immobilized HRP, respectively. A smaller decolorization efficiency of immobilized HRP can be due to diffusion limitations and more difficult approach of the substrate to the active site. Namely, during the adsorption, enzyme molecules can be densely packaged, forming an obstacle to the incoming substrate molecule and thus lowering the decolorization power of immobilized HRP molecule [14]. Besides, for the immobilization unpurified HRP was used, where number of impurities could also adsorb on the support surface and hinder the bound HRP active center. Under the optimal $\mathrm{pH}$, optimal concentration of hydrogen peroxide was evaluated. It is evident from Fig. $1 \mathrm{~b}$ that immobilization of HRP resulted in reduced adverse impact of hydrogen peroxide on the peroxidase activity. By increasing the concentration of hydrogen peroxide up to $0.1 \mathrm{mM}$, increase in decolorization efficiency is evident. With further increase in hydrogen peroxide concentration decolorization of AV 109 dye falls off sharply using free peroxidase. On the other hand, using immobilized HRP a slight decrease in the decolorization at hydrogen peroxide concentration of $0.2 \mathrm{mM}$ is evident, where from further increase in hydrogen peroxide concentration resulted in almost constant decolori- zation of AV 109 dye. Nevertheless, after immobilization of HRP on fumed silica, hydrogen peroxide inhibitory effect is reduced. After $\mathrm{pH}$ and hydrogen peroxide, optimum dye concentration was examined (Fig. 1c). Apparently, immobilization had protective effect on the HRP because inhibitory influence of dye was less pronounced. In both cases, optimum dye concentration was $30 \mathrm{mgL}^{-1}$, where $53.2 \%$ and $72.3 \%$ of AV 109 dye was decolorized using immobilized and free peroxidase, respectively. Increasing the dye concentration exerted a strong inhibitory effect on free HRP as opposed to immobilized, which has proven to be considerably less sensitive to the inhibition by AV 109 dye.

Industrial application of enzymes is based on the possibility to use immobilized biocatalyst more times in the desired reaction. Under the optimal conditions, operational stability of immobilized peroxidase was examined (Fig. 2a). Through three consecutive cycles higher decolorization efficiency of imobilized than free HRP was evident. Namely, after three cycles immobilized HRP decolorized $27.0 \mathrm{mg} \mathrm{L}^{-1}$ of AV 109 dye, meanwhile free HRP $21.0 \mathrm{mgL}^{-1}$. It is evident that after third cycle peroxidase lost its catalytic activity probably because of active center covering by reaction products [15]. In addition, immobilized HRP obtained in this study was more effective than dyedecolorizing peroxidase which has maintained its activity during only two cycles of application [16]. Fig. $2 \mathrm{~b}$ donates the UV-Vis spectra of the initial dye solution as well as the spectra of dye solutions after decolorization with free and immobilized HRP (the first reaction cycle). Although a higher decolorization was observed with free HRP, the 
immobilized HRP can be applied in three consecutive cycles which clearly indicates the advantage of application of immobilized HRP in comparison to the free HRP. If we take into account that peroxidase used in this study was

a)

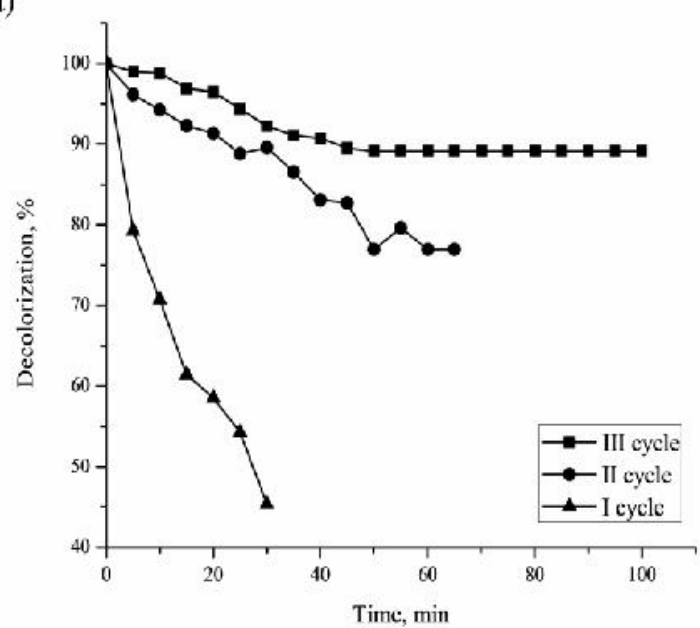

from fresh horseradish roots extract, the obtained results indicate a high potential of unpurified HRP application in the decolorization reactions, significantly increasing the economic feasibility of the overall process.

b)

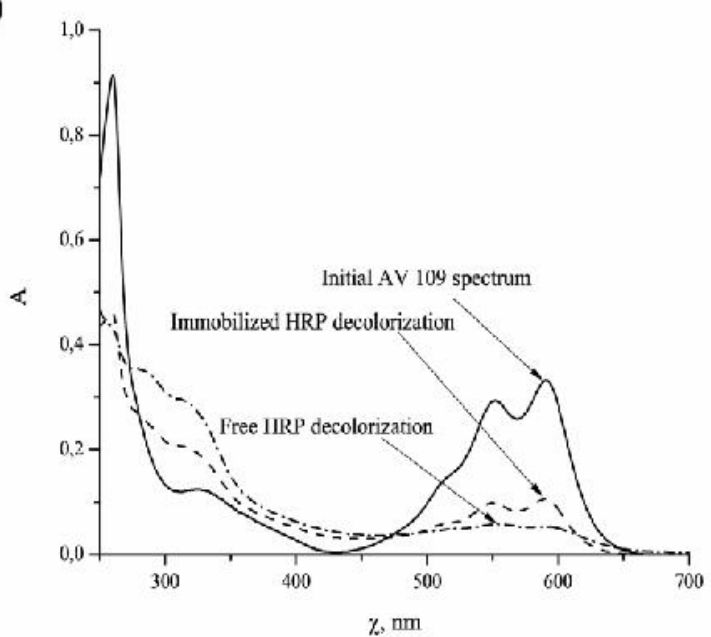

Figure 2 - a) reusability (reaction volume $50 \mathrm{~mL}$, enzyme $0.1 \mathrm{IU}$, dye concentration $30 \mathrm{mg} \mathrm{L}^{-1}, \mathrm{pH} 4.0$, hydrogen peroxide concentration $0.1 \mathrm{mM}$ ); b) Initial, after decolorization with free and immobilized HRP AV 109 spectrum

\section{CONCLUSION}

In this paper a significant effort was made for the optimization of enzyme catalyzed anthraquinone dye decolorization from wastewater. The obtained results represent a good base for the industrial scale biocatalyst development. Further research should be directed towards optimizing the immobilization procedure. Additionally, increasing the stability of the resulting biocatalyst should also be the subject of further studies. The development of a stable biocatalyst leads to the ultimate objective, which is application in the appropriate bioreactor configuration with high efficiency.

\section{Acknowledgments}

The authors acknowledge the financial support of the Ministry of Education, Science and Technological Development of the Republic of Serbia (project number III-46010 and 172013).

\section{REFERENCES}

[1] W. Ou, G. Zhang, X. Yuan, P. J. Su (2015) Experimental study on coupling photocatalytic oxidastion process and membrane separation for the reuse of dye wastewater, Journal of Water Process Engineering 6, 120-128.

[2] D. Deng, J. Guy, G. Zeng, G. Sun (2008) Decolorization of anthraquinone, thriphenylmethane and azo dyes by a new isolated Bacillus cereus strain DC11, International Biodeterioration \& Biodegradation 62, 263-269.
[3] J. Fachiang, D. H. Tseng (2009) Degradation of anthraquinone dye C.I. Reactive Blue 19 in aqueous solution by ozonation, Chemosphere 77, 214-221.

[4] M. Celebi, M. A. Kaya, M. Altikatoglu (2013) Enzymatic decolorization of anthraquinone and diazo dyes using horseradish peroxidase enzyme immobilized onto various polysulfone supports, Applied Biochemistry and Biotechnology 171, 716730.

[5] T. Robinson, G. McMullan, R. Marchant, P. Nigam (2001) Remediation of dyes in textile effluent: a critical review on current treatment technologies with a proposed alternative, Bioresource Technology 77, 247-255.

[6] N. Šekuljica, N. Prlainović, A. Stefanović, M. Žuža, D. Čičkarić, D. Mijin, Z. Knežević-Jugović (2015), Decolorization of anthraquinonic dyes from textile effluent using horseradish peroxidase: Optimization and kinetic study, Scientiffic World Journal 2015, Atricle ID 371625, p.12.

[7] S. V. Guo, F. Zhang, B. Zheng, J. L. Zhang, X. L. Huang, H. Liu, J.Y. Zhang (2010) Horseradish peroxidase immobilized on graphene oxide: physical properties and applications in phenolic compound removal, The Journal of Physical Chemistry C 114, 8469-8473.

[8] Q. Husain (2006) Potential applications of the oxidoreductive enzymes in the decolorization and detoxification of textile and other synthetic dyes from polluted water: a review, Critical Reviews in Biotechnology 26, 201-221.

[9] I. F. Mironyuk, V. M. Gun'ko, V. V. Turov, V. I. Zarko, R. Leboda, J. Skubiszewska-Zieba (2001) 
Characterizations of fumed silicas and their interactions with water and dissolved proteins, Journal of Colloid Surface A 180, 87-101.

[10] S. A. Mohamed, A. S. Aly, T. M. Mohamed, H. A. Salah (2008) Immobilization of horseradish peroxidase on nanowoven polyester fabric coated with chitosan, Applied Biochemistry and Biotechnology 144, 169-179.

[11] E. F. Hartree (1972) Determination of protein: A modification of the Lowry method that gives a linear photometric response, Analitycal Biochemistry 48, 422-427.

[12] T. Cvetić, A. Sabovljević, J. B. Pristov, M. Sabovljević (2009) Effects of day length on photosynthetic pigments and antioxidative metabolism of in vitro cultured moss Atrichumundulatum (Hedw.) P. Beauv. (Bryophyta), Botanica Serbica 33, 83-88.
[13] K. Nakanishi, T. Sakiyama, K. Imamura (2001) Review on the adsorption of proteins on solid surfaces, a common but very complicated phenommenon, Journal of Bioscience and Bioengineering 91 233-244.

[14] J. Zhu, G. Sun (2012) Lipase immobilization on glutaraldehyde-activated nanofibrous membranes for improved enzyme stabilities and activities, Reactive and Functional Polymers 72, 839-845.

[15] R. Zhai, B. Zhang, Y. Wan, C. Li, J. Wang, J. Lin (2013) Chitosan-halloysite hybrid-nanotubes: Horseradish peroxidase immobilization and applications in phenol removal, Chemical Engineering Journal 214, 304-309.

[16] M. Shakeri, M. Shoda (2008) Decolorization of an anthraquinone dye by the recombinant dyedecolorizing peroxidase (rDyP) immobilized on mesoporous materials, Journal of Molecular Catalysis B: Enzymatic 54, 42-49.

\section{IZVOD}

\section{IMOBILIZACIJA PEROKSIDAZE IZ SVEŽEG EKSTRAKTA RENA I PRIMENA U DEKOLORIZACIJI ANTRAHINONSKIH BOJA}

Sintetičke boje se primenjuju u gotovo svim granama u industriji i predstavljaju ozbiljan ekološki problem. Po zastupljenosti, antrahinonske boje se nalaze na drugom mestu, odmah posle azo boja. Za razliku od azo boja, antrahinonske boje se zbog prisustva kondenzovanih aromatičnih prstenova teže razgrađuju. Peroksidaza iz rena se pokazala kao efikasno i ekološki prihvatljivo rešenje za dekolorizaciju sintetičkih boja. Iz tog razloga je predmet ovog rada mogućnost primene neprečišćene peroksidaze iz svežeg ekstrakta rena u dekolorizaciji antrahinonskih boja. Neprečišćena peroksidaza $\left(1.5 \mathrm{mg} \mathrm{mL}^{-1}\right)$ imobilisana je adsorpcijom na silikatne čestice. $0.1 \mathrm{IU}$ dobijene imobilisane peroksidaze je upotrebljena u cilju optimizacije dekolorizacije antrahinonske boje AV 109 u šaržnom reaktoru. Pod optimizovanim uslovima $\left(\mathrm{pH} 4.0\right.$, koncentracija boje $30 \mathrm{mg} \mathrm{L}^{-1}$, koncentracija vodonik-peroksida 0.1 $\mathrm{mM}$, vreme kontakta 40 minuta), $55.1 \%$ ispitivane boje je uklonjeno. Pored toga, imobilizacijom je značajno umanjen inhibitorni uticaj boje i peroksida na peroksidazu.

Ključne reči: peroksidaza iz rena, imobilizacija, boje, otpadna voda.

Naučni rad

Rad primljen: 15. 04. 2015.

Rad prihvaćen: 16. 06. 2015.

Rad je dostupan na sajtu: www.idk.org.rs/casopis 